\title{
The Effect of Quality Management Systems on the Performance of Food Processing Firms in Kenya.
}

\author{
${ }^{1}$ Evelyn Nyakio Kibe, ${ }^{2}$ Dr. Kenneth Wanjau \\ ${ }^{1}$ School of Human Resource and Development, Jomo Kenyatta University of Agriculture and Technology, \\ ${ }^{2}$ P O Box 62000-00200 Nairobi Kenya
}

\begin{abstract}
The impact of quality management systems (QMS) on performance remains controversial with a number of empirical studies alluding to nullity of ISO certification on performance. Owing to this contradiction and lack of empirical studies in Kenya, this paperexplores quality management systems and their influence performance of food processing firms in Kenya, where, food processing companies still find it challenging to effectively implement quality managements systems that contribute towards realization of increased organization performance. Over $75 \%$ of food processing companies in Kenya are still struggling to embrace effective quality management systems as a strategy to gain a competitive edge in the target market through development of superior product quality, market growth and higher customer satisfaction.

The paper makes an important contribution, offering deeper insights into the benefits of quality management systems, practices and principles that managers should take into account for any certification whether ISO, TQM or HACCP to be successfully implemented and consequently translate to increased organization performance. The study found that quality management practices under study have a strong positive correlation with an organizations' competitive performance. These quality practices are critical in achieving and maintaining this competitive performance, they include top management support, capacity enhancement, adoption and utilization of information technology and control measures.

The study therefore recommends that food processing firms focus should thus be on modifying the culture of the whole organization with a view to transforming it into an overtly quality-oriented culture, for the firm to achieve the benefits of a quality management system, it is critical to regularly run training in this area with the aim of instilling habits and make workers more receptive to the change of working methods. The implementation of quality management techniques enables organizations to improve internal efficiencies, which is considered as a prerequisite to become competitive in global marketplace.
\end{abstract}

\section{Introduction}

Quality management is the way in which an organization determines and implements systems to ensure that quality, in the sense that specifications are met, are achieved (Freeman-Bell and Grover, 1994). The British Standards BS EN ISO 8402:1995 define quality management more broadly as all activities of the overall management function that determine the quality policy, objectives and responsibilities, and implement them by means such as quality planning, quality control, quality assurance and quality improvement within the quality system.

Dean \& Bowen, (1994); Wilkinson et al., (1998); Dale et al., 2000; Dale, (2003) and van Iwaardeen et al., (2006) concluded that quality management consists of three core building blocks; customer orientation, process control, and continuous improvement and its aim is to control an organization's processes and to improve and change these processes in response to changes.Terziovski et al. (1999) and Singh (2003) suggest the three practical approaches that organizations use to implement quality management are the standard-based approach (e.g. the ISO 9000, ISO 22000 standards), the prize criteria approach (i.e. the various national and regional business excellence or quality awards such as the US Malcolm Baldrige National Quality Award (MBNQA) and Australian Business Excellence Award (ABE), and the elemental approach that consists of the many ideas promoted by consultants and experts in the area. Due to its importance, there must be some ways quality can be managed by the organizations. The theories for the management of quality in organizations can be developed by looking at several sources namely; the quality gurus' perspectives, empirical research, and formal evaluation models. 


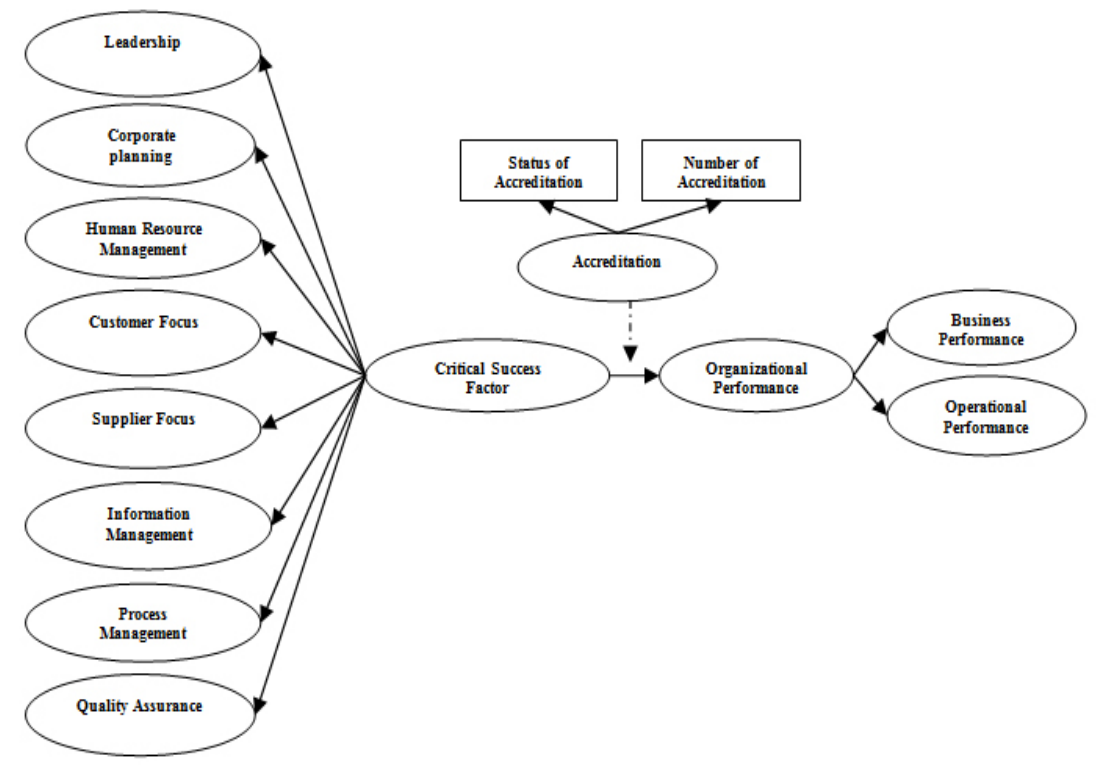

A quality management framework for SME's in food processing industry (Hayati and Idris, 2013)

Quality management is seen as a strategic tool to improve organizational performance in both large and small businesses and in any part of the world. One would ask, what is quality management after all? To answer what quality management is; it must be understood that different writers mention the term quality management differently, however it basically mean the same thing. It is sometimes referred to as strategic quality management, total quality management (TQM) or simply put quality management. The authors prefer to use quality management in this study (Evans and Lindsay, 1993) stated that TQM "implies that quality is not solely a control or technical issue but that must be addressed from the perspective of strategic management". Flynn (1994) also defines quality management as "an integrated approach to achieving and sustaining high quality output". Department of Trade and Industry (2004) in the UK defines quality management, best practice management or modern management as doing things right first time. (Evans, 1996) said, "quality management practices today simply represent sound management practices and that practices once regarded as quality management activities are now viewed as generic management activities"

\subsection{Food Safety Assurance Systems}

These systems have been established to assure food safety, and are subsequently called "safety assurance systems". These include Good Hygiene Practices (GHP), Good Manufacturing Practices (GMP) and Hazard Analysis and Critical Control Point (HACCP). Good Manufacturing Practices (GMP) is a set of guidelines specifying activities to be undertaken and conditions to be fulfilled in food manufacturing processes in order to assure that the food produced meets the standards of food safety. Similarly, Good Hygienic Practices (GHP) constitute a set of guidelines specifying activities to be undertaken and hygienic conditions to be fulfilled and monitored at all steps of the food chain in order to assure food safety.

Both GMP and GHP constitute a precondition in a food enterprise for implementing the HACCP system.

Hazard Analysis and Critical Control Point (HACCP) is currently defined by the Hygiene Rules 93/43/EEC in the production line of food in Europe. It comprises the main ideas from the worldwide accepted HACCP-System of the FAO/WHO Codex Alimentarius. It is a systematic food safety assurance method to identify, evaluate and control of food hazards. The HACCP system consists of 12 stages of implementation, of which five are preliminary tasks and seven are HACCP principles (Codex Alimentarius, 2001).Food safety should be given the highest priority, however companies are often short of time and appropriate personnel require training, especially in food safety, which needs to be widely disseminated throughout their company. Food safety management systems are much more likely to be effective if they are owned by all in production and management.

Hazard Assessment of Critical Control Points (HACCP) aims the identification, evaluation and control of steps that are critical to product safety in the food technological chain. HACCP enables the management of a cost effective, ongoing food safety programme. HACCP is a tool to assess hazards and establish control systems that focus on prevention rather then end product testing. For the implementation of a HACCP based approach to food safety, the responsibility involves: Industries involved in food chain, Policy makers and mangers who can 
The Effect of Quality Management Systems on the Performance of Food Processing Firms in Kenya.

facilitate the adoption of HACCP systems, Government authorities, including legislators, regulatory food control officials and health education bodies. (Codex Alimentarius, 2001).

\subsection{Hazard Analysis Critical Control Point (HACCP)}

In the 1960's, the Pillsbury Company in cooperation with the National Aeronautic and Space Administration (NASA) first constructed HACCP to describe the systematic approach to food safety. The goal of the program was to come as close to $100 \%$ assurance as possible that the food produced for space use would not be contaminated with bacterial or viral pathogens, toxins, chemicals or physical hazards that could cause an illness or injury (Pierson and Corlett, 1992). The HACCP has become widely used and developed. It is now a legislative requirement in USA, Canada and EU-countries. Some countries such as Australia, New Zealand, Canada, Japan, Egypt, South Africa, Kenya and many others have also adopted or are considering food safety control systems based on HACCP. HACCP system is universally endorsed by international bodies such as Codex Alimentarius Commission, Food and Agriculture Organization, and World Health Organization.

Hazard Analysis Critical Control Points (HACCP) is an international, auditable standard that specifies the requirements for food safety management systems together with a comprehensive management system (Pillay and Victor, 2006). The ISO 22000 standard incorporates GMP and addresses Hazard Control based on HACCP development and it is set up around the HACCP method (Talbot, 2007). Arvanitoyannis and Varzakas (2008, 2009) carried out a comparison study between ISO 22000 and HACCP. They found out that the Prerequisite Programs (PRPs) are the main difference between the two systems. The ISO 22000 standard and HACCP system is regarded worldwide as an effective means of assuring food safety, food handling, processing and retail sales to consumers, which is applied throughout the whole food chain (Loc, 2006; Domenech, Escriche \&Martorell, 2008).

HACCP approach is the basic element of the ISO 22000 and the effectiveness of the HACCP system affects the implementation of ISO 22000. The hazards' identification, assessment and control are the basic aims of the HACCP system that affect its effectiveness (Domenech et al., 2008; Burlingame and Pineiro, 2007; Trienekens and Zuurbier, 2008). In addition, the HACCP standard predetermines the requirements for a food safety management system that combines the prerequisites, the mutual communication of the company in the food chain and the effectiveness of the company's traceability system (ELOT, 2005). Previous researchers like Sperber (1997, Ababouch (2000), Mortimore (2000) and Wallace and Powell (2005), as well as by the ISO 22000 standard's requirements have proposed various measurement variables; (hazards' identification, assessment and control, implementation of prerequisite programs, effectiveness of the traceability system, mutual communication of the company in the food chain) to measure the effectiveness of HACCP implementation.

Hazard Analysis Critical Control Point (HACCP) is a food safety management system, which concentrates prevention strategies on known hazards and the risks of them occurring at specific points in the food chain. It is this specificity which makes HACCP so effective and the approach easily integrates into Total Quality Management or ISO 9000. Developing HACCP assists companies to comply with legislation, supports due diligence and fulfils customer requirements for a food safety management system.

\subsubsection{The Seven Principles of HACCP}

Hazard Assessment of Critical Control Points (HACCP) aims the identification, evaluation and control of steps that are critical to product safety in the food technological chain. HACCP enables the management of a cost effective, ongoing food safety programme. The proper identification of CCPs (Critical Control Points) is a key issue in HACCP, because the major efforts in process control should be directed towards these steps (Damikouka and Tzia, 2007). For the practical application of the HACCP concept according to Codex Alimentarius, seven rules have to be followed which are laid down in seven main principles and constitute the basis for the establishment of a HACCP plan, all of them must be considered in its practical application (Almeida, 1998; UNIHSNOR, 2005):

1st Principle: Conduct Analysis

Hazard analysis and identification of preventive measures; this phase identifies the physical, biological and chemical hazards in each process set defined in the flowchart;

2nd Principle: Identify CCPs

Identification of the Critical Control Points (CCP); the identification of Critical Control Points is established according to the decision tree;

3rd Principle: Establish Critical Limits 

involved;

The establishment of critical limits is essential for consistency in the safety analysis of the processes

4th Principle: Establish a Monitoring System

Establishment and implementation of monitoring procedures to control the CCP; It is important to assess whether the CCP is effectively under control through proper monitoring procedures;

\section{5th Principle: Establish Corrective Actions}

Determine corrective actions in case of deviation of critical limits; this principle intends to establish actions to correct deviations in the monitoring of each CCP;

6th Principle: Establish Verification Procedures

Establishing systems for recording and archiving data that document the HACCP; this principle intends to establish procedures to ensure that the HACCP plan is being effective;

\section{7th Principle: Documentation}

Procedure to assess whether the HACCP system is working properly; this principle aims to define the procedures for the keeping of records and documentation relating to the plan. These procedures are monitoring, sampling, analysis, audit of HACCP, validation of critical limits (confirming that the CCP is kept under control) and inspection of manufacturing processes.

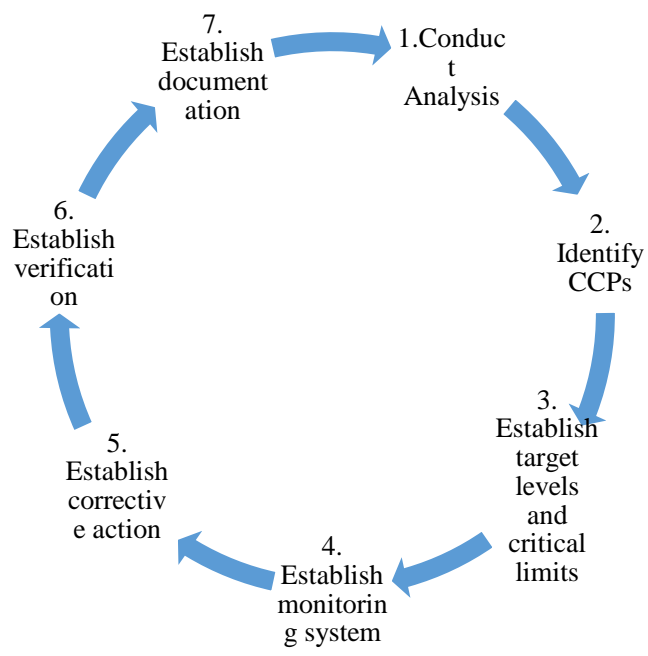

Fig 2: The Seven Principles of HACCP (Codex Alimentarius, 2003)

\subsubsection{The HACCP Plan}

The HACCP system consists of 12 stages of implementation, of which five are preliminary tasks and seven are HACCP principles (Codex Alimentarius, 2003). The HACCP plan must be $100 \%$ focused on food safety. The most important HACCP concept is that it relies on prevention rather than inspection. HACCP is an evolving concept that continues to change and improve food quality. Hazard Analysis Critical Control Point system is unique for each company and must be introduced individually for each enterprise and production line to bring a stronger emphasis to the effective implementation of the food business processes. (Sikora and Strada, 2008) 


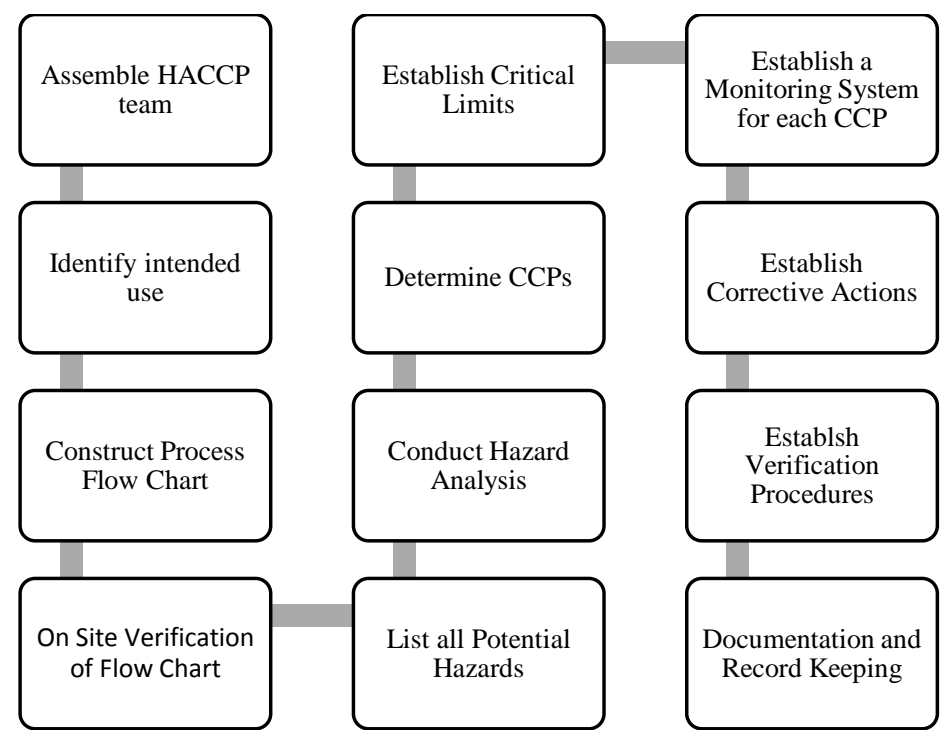

Fig 3: The HACCP Procedure (Codex Alimentarius, 2003)

\subsection{Organizational Performance}

Organizational performance measurement has become more crucial for the survival of companies in today's globalization market (Brah Tee, and Rao2002). Thus the development of the performance measurement system that satisfies the company's business requirement is necessary to enable the company to achieve its desired business performance. Performance measurement will allow companies to pay more attention to the area they are lacking (Skrinjar, 2008). Business performance has been calibrated with financial measures, operational measures, service performance and customer satisfaction measures by including multiple aspects of performance. Several authors have proposed different quality measures that affect business performance. Literature has identified different variables used for measuring organizational performance as shown in Table 1.

Table 1: Performance Measures (Hayati, Ali and Idris, 2012)

\begin{tabular}{|c|c|c|}
\hline Author(s) & Measure & Variables \\
\hline Chong.(2001) & Performance improvement & $\begin{array}{l}\text { Quality (internal quality; external quality); Productivity (labor } \\
\text { productivity; employee behavior; throughput time; inventory } \\
\text { levels; Unit cost) }\end{array}$ \\
\hline Husain et al.(2001) & Total performance & Revenue; profit; market share; image \\
\hline Brah, Tee and Rao.(2002) & Quality Performance & $\begin{array}{l}\text { Product/service quality; Employee and service quality; Process } \\
\text { quality; Supplier performance }\end{array}$ \\
\hline Ahmed and Hassan (2003) & Performance measure & Sales; overall competitiveness; cash flow; exports; market share \\
\hline Naser et al.(2004) & Financial performance & Economic value added; return on sales; free cash flow \\
\hline Agus (2000) & Financial performance & Total assets; Net profit \\
\hline $\begin{array}{l}\text { Sila and Ebrahimpour } \\
(2005)\end{array}$ & Business result & $\begin{array}{l}\text { Customer focus result; Human resource results; Financial and } \\
\text { market results; Organizational effective result }\end{array}$ \\
\hline Lakhal et al.(2006) & Organizational Performance & Financial performance; Operational performance; Product quality \\
\hline Tari and Sabater.(2007) & Quality outcomes & $\begin{array}{l}\text { Customer results; people result; society results; quality } \\
\text { performance }\end{array}$ \\
\hline Singh, Feng Smith. (2008) & Organizational performance & $\begin{array}{l}\text { Operational performance (cost reduction; increased productivity } \\
\text { etc.); Business performance (increase market share, corporate } \\
\text { image etc.) }\end{array}$ \\
\hline Arumugam.(2008) & Quality performance & $\begin{array}{l}\text { Quality of product and service; customer relations, customer } \\
\text { satisfaction; level of quality performance }\end{array}$ \\
\hline Škrinjar.(2008) & Organization performance & Financial ; Non financial \\
\hline Su et al. (2008) & Organizational performance & Quality performance ; business performance; R\&D performance \\
\hline Jusoh and Parnell (2008) & Performance measurement & $\begin{array}{l}\text { Financial measure; customer measure; internal business process } \\
\text { measures; learning and growth measures }\end{array}$ \\
\hline $\begin{array}{l}\text { Fotopoulos and Psomas } \\
(2009)\end{array}$ & TQM result & $\begin{array}{l}\text { Customer satisfaction; employee satisfaction; impact on society; } \\
\text { business result }\end{array}$ \\
\hline Zakuan et al.(2010) & Organization Performance & Business Result, Level of Satisfaction \\
\hline
\end{tabular}

\section{Conceptual Framework}

A conceptual framework can be defined as a set of broad ideas and principles taken from relevant fields of enquiry and used to structure a subsequent presentation (Bogdan, 2007). The conceptual framework is used to show the relationship between the independent variables and dependent variable. In this study, the independent variables are top management support, capacity enhancement, information technology and control measures. 
The dependent variable is the performance of food processing firms. In recent times the concept of quality has been a concern for most businesses. There have been studies regarding the relationship between certain variables of quality management and performance.

Considerable amount of such studies have been devoted to planning and performance of organizations (Aram and Cowen, 1990; Wijewardena et al., 2004; Yusuf and Saffu, 2005), human resource management and performance (Huselid, 1994; Huang, 2001; Marlow and Hannon, 2000), and leadership and firm performance (Anderson and Sohal, 1999). There have also been studies about the relationship between quality management and quality performance. Most of these are based on empirical studies (Ahire and Golhar, 1996; Dow et al., 1999; Flynn et al., 1994). Other studies (Adam, 1994; Powell, 1995; Samson and Terziovski, 1999) linked performance measures to quality products.

The conceptual framework proposed in this paper is developed based on these previous models and in addition, elements of the international and national quality awards, such as the Deming Prize (Japan), Malcom Baldrige National Quality Award (United State), European Foundation Quality Award (European) have considered in the conceptual framework for assessing the quality management practices in food processing firms in Kenya

Thus the study framework includes: (top management support, capacity enhancement, information technology and control measures. The dependent variable is performance, which will be measured by several indicators. There is always a difficulty as to which performance indicator to use for such a study. This is because there are methodological issues. The performance indicators for this study will include profitability, sales growth, customer satisfaction, employee morale, cost reduction, product quality and market share. Some of these performance indicators have been used in previous studies (Yusuf and Saffu, 2005; Lerner and Almor, 2002; Saffu and Manu, 2004).

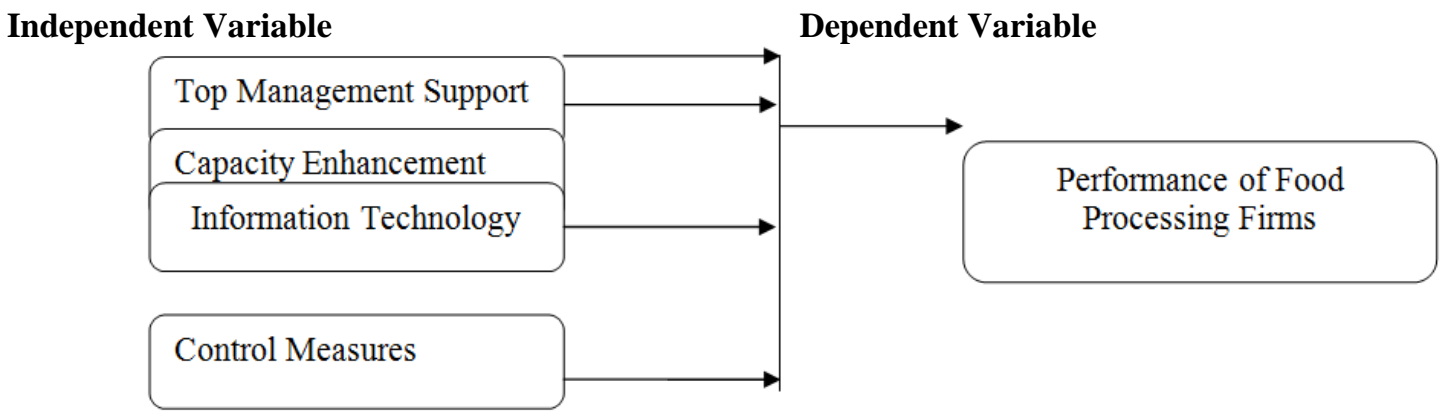

Fig 4: Conceptual Framework

\subsection{Top Management Support}

The study looks at leadership specifically managerial support and commitment and how it improves organizational performance with emphasis on small firms. This is about how senior managers in the organization guide the company in setting organizational values, directions and performance expectations. Research has shown that quality leadership enhances organizational performance (Anderson and Sohal, 1999). Evans emphasized the leadership of an organization that promote quality and high performance "create a strategic vision and clear values which serve as a basis for all business decisions at all levels of the organization and that the vision and values revolve around customers".

\subsection{Capacity Enhancement}

Human resources are the most dynamic of all the organization's resources. Where an organization has a well-trained workforce, it can produce better jobs, they can be creative and innovative. The main issue addressed is to what extent has the workforce been developed and realized through the human resource practices, employee involvement, teamwork and training in the company. According to Tari et al. (2007), the management of human resource is the factor that has a greater effect on quality outcomes. Employee empowerment practices can improve internal and external quality results (Yoo et al., 2006). According to Samson and Terziovski (1999), a commonly heard statement from the top management is, "people are our critical resources" and "people are everything". As a result, it led to an expectation that this construct will have a significant effect on the organizational performance. The success of quality management systems and their adoption relies more on executive commitment, open organization and employee empowerment. (Wanjau, 2012) The implementation and effective functioning of a HACCP system require knowledge of the hazards inherent to the infrastructures, tools and human resources. A HACCP system that really works in practice will depend on the competency of the people who both developed and operate it, and the prerequisite programs, that support it (Mortimore, 2001). 


\subsection{Information Technology}

More and more organizations are now adopting the same strategy of total quality and at the same time seeking to make maximum use of IT to increase their performance. Many researchers have demonstrated the positive impact that both quality management $(\mathrm{QM})$ and IT can have on organizational performance. Moreover, the majority of organizations nowadays have the necessary capabilities to successfully manage quality and also necessary resources to acquire necessary ITs; this has given birth to a new requirement, which is to successfully combine QM and IT.

Information is a critical enabler for quality management. More and more successful companies agree that information technology and information systems are keys to their (quality) success.

Three categories of information are mentioned as being crucial to quality management: operational information with an emphasis on process management, action plans and performance improvement; comparative information related to comparative position and best practices, both having an operational and strategic value; and information that relates process management to business performance by providing an insight into cause/effect relationships (Ross, 1999).

Information technology has many effects, including the improvement of performance and the affection of organizational structure. It helps firms to retrieve information faster and more conveniently, and this enhances decision-making.

Most literature on total quality management suggests that an organization that consistently collects and analyzes information efficiently will be more successful than those that do not (Samson and Terziovski, 1999). However, the core practice of information and analysis has a direct and significant effect on both operational and financial performances (Lakhal et al., 2006).

Core communicative technologies (CCTs), such as project portals and e-mail communication technologies, enable project teams to solicit customer and supplier involvement in key project decisions which can lead to improvements in the quality of project decisions. They also facilitate re-use of product data and other knowledge assets within and across project teams. Other technologies, such as groupware and instant messaging software, enable easier tracking of projects and improve project visibility. (Carte and Chidambaram, 2004). ECTs, such as document management systems and knowledge management systems, provide efficient electronic storage and enable quick information retrieval which improves process efficiency.

\subsection{Control Measures}

This element is concerned with the way the organization manages a combination of machines, tools, methods, materials and people engaged in a production process. It encompasses process management which involves the systems and procedures for establishing quality in the many shop floor activities involved in manufacturing. Additionally, this element is given a lot of attention by management by using various tools and techniques (Sharma and Kodali, 2008). It is also concerned with how the organization manages, evaluates and improves its key processes for quality output. This is supported by Tari et al. (2007), process management influences continuous improvement and leads to quality outcomes. In addition, the integration of process management together with the continuous quality improvement will lead to quality products and services (Tata et al., 2000).

\subsection{Performance measures}

The definition of performance is not clear among researchers and academics. Depending on the topic of study, different researchers have different indicators to measure performance. There are some issues as already indicated and therefore the difficulty as to which indicator to use.

The performance indicators for this study will include profitability, customer satisfaction, sales growth, employee morale, and market share. Some of these performance measures have been used in previous studies (Yusuf and Saffu, 2005; Lerner and Almor, 2002; Saffu and Manu, 2004).

\section{Empirical Review}

Powell (2009) found out that attempts to test the link between quality management practices and organizational performance are beginning to emerge and improvements in quality are likely to increase productivity, performance and profits. Dow (2007) noted that performance refers to the way an organization's service quality can be measured, including its impact on business performance and there is a strong relationship between quality management practice and performance. Crosby (2009) found out that TQM philosophy and methods can lead to improvement in business and operational performance, such as: improved process yields, motivated employees, satisfied customers, improved quality, productivity and profitability. The scope of performance outcomes, based on quality initiatives, therefore, appears to be very broad.

PIMS (2007) (Profit Impact of Marketing Strategies) conducted the most authoritative study of the link between quality practice and business results. The PIMS study used a database of over 3,000 companies in 
North America and Europe and its results reinforce the point that quality is the most effective strategic weapon available to organizations. Buzzell and Gale (2007) stated that in the long run, the most important factor affecting a business unit's performance is the quality of its products and services relative to those of competitors. The PIMS results have repeatedly shown that there was a significantly positive correlation between quality and profit. The higher the relative quality, the higher the average returns on investment and return on sales.

As a rule of the thumb, the PIMS study found that for every 2 per cent improvement in the rating of an organization's quality by its customers, there is a 1 per cent increase in the company's return on investment (Buzzell and Gale, 2007).A study by Voss (2007) developed model of service management to establish a benchmark against which the practice and performance of $310 \mathrm{UK}$ and US organizations were measured among a broad range of service industries. The study was "based on the proposition that best practice in service management leads to high service performance which, in turn, leads to superior business performance. The implementation of quality management practices has a positive impact on overall performance outcomes in the organization. Key areas of performance outcomes used in testing this proposition were improved competitive advantage and increased productivity. As quality initiatives emphasizes the involvement of employees, and it has been demonstrated that such involvement results in higher levels of employee morale, employee morale is also adopted as one of the performance outcomes that may relate to quality management. Finally, as quality management advocates enhanced relationships with both customers and suppliers at all stages of the design and delivery of services, enhanced customer and supplier relationships are also explored as likely performance outcomes. As well as facilitating significantly improved overall organizational performance, there is evidence in the literature that quality management practices will result in improved operational efficiencies in organizations (Flynn, 2007). The work of Parasuraman (2008) in determining the dimensions of service quality suggests that there are five major process dimensions - tangibles, reliability, responsiveness, assurance and empathy - which are broadly applicable across service industries.

Roth (2009) found out that the implementation of quality management practices will have a positive effect on operational performance in the organization, the key areas of operational performance used to test this proposition were improved systems, increased quality of service, increased throughput, improved response to customer needs, improved timeliness of delivery, increased accuracy of work, reduced rework and reduced cost of poor quality.

Alison (2008) studied the impact of TQM and related improvement strategies on performance of Australian SMEs by using Australian Quality Awards framework to determine the relationship between TQM practices and business performance. They observed a positive correlation between TQM practices and organizational performance of the SMEs, reiterating the need for effective implementation of the TQM practices along with strategic decision making which will ultimately yield long-term fruitful results for SMEs. Chen (2008) explored the impact of TQM and market competition on organizational performance by studying filled acceptable questionnaires from 89 managers from manufacturing firms.

Results showed that there is a positive correlation between market competition and TQM practices of customer focus, product design and organizational performance. Powpaka (2009) investigated the existing status of TQM practices in 112 SMEs (manufacturing firms) of China and its impact on their performance. It was found that manufacturing process of these small firms was not an obstacle to the implementation of TQM; instead it was the size of firm which posed as a threat for implementation. Research showed that majority of the firms were new to TQM practices and that it was initiated by their top management. A positive influence of TQM was observed on performance as waste, inventory and costs was reduced, and an increase in sales was observed. Impeding factors in TQM implementation were lack of top management commitment and lack of knowledge about TQM implementation, along with lack education and training and inadequate process control techniques.

According to Flynn (2009), quality management is defined as an integrated approach of achieving and sustaining high quality output, focusing on the maintenance and continuous improvement of process and defect prevention at all levels and functions of the organization, in order to meet or exceed customer's expectation. This definition was used as a guide in the development of the proposed framework in the study of quality management practices in the SMEs in Malaysian food industry. Moreover, quality management is a key element in the World Class Manufacturing approach of achieving and sustaining a competitive advantage. Quality Management is a critical component in both design and production of products which are superior to competitors' products (Flynn, 2009).

One of the most popular and often recommended approaches is the philosophy of Total Quality Management (TQM) that seeks to integrate all the organizational functions, focusing on meeting customers' requirement and organization objectives. Patrick (2011) found out that in Egypt and South Africa most food processing companies have embraced effective quality management systems such as IS0 9001:2008 and this has enabled them to achieve a competitive advantage in the global market hence leading to increased organization 
performance. A study by Anderson (2009) noted that, in Kenya, most food processing companies experiences a declined performance in terms of low sales revenue due to lack of effective quality management systems such as IS0 9001:2008. Many food processing firms are currently struggling to embrace effective quality management systems in order to meet customers' demands in the global market (Anderson, 2009). Musa (2009) found out that in Kenya, the food industry is one of the potential and an important industry in Kenya and therefore it is necessary to ensure the conformity, assurance and trustworthiness of the quality of food products. The quality of a food product is referred to be in every single aspect of the food including the safety, nutrition and hygiene.

A number of TQM implementation instruments have already been developed by different researchers, for example, Ahire et al. (1996), Flynn et al. (1994), Saraph et al. (1989), Raghunathan et al. (1997), Sun (2000) and Zhang et al. (2000), this study combines the key elements to provide our own index. Table 2.1 maps out the elements of quality proposed by various authors and researchers.

Table 2: Evaluation instruments previously used to index quality management

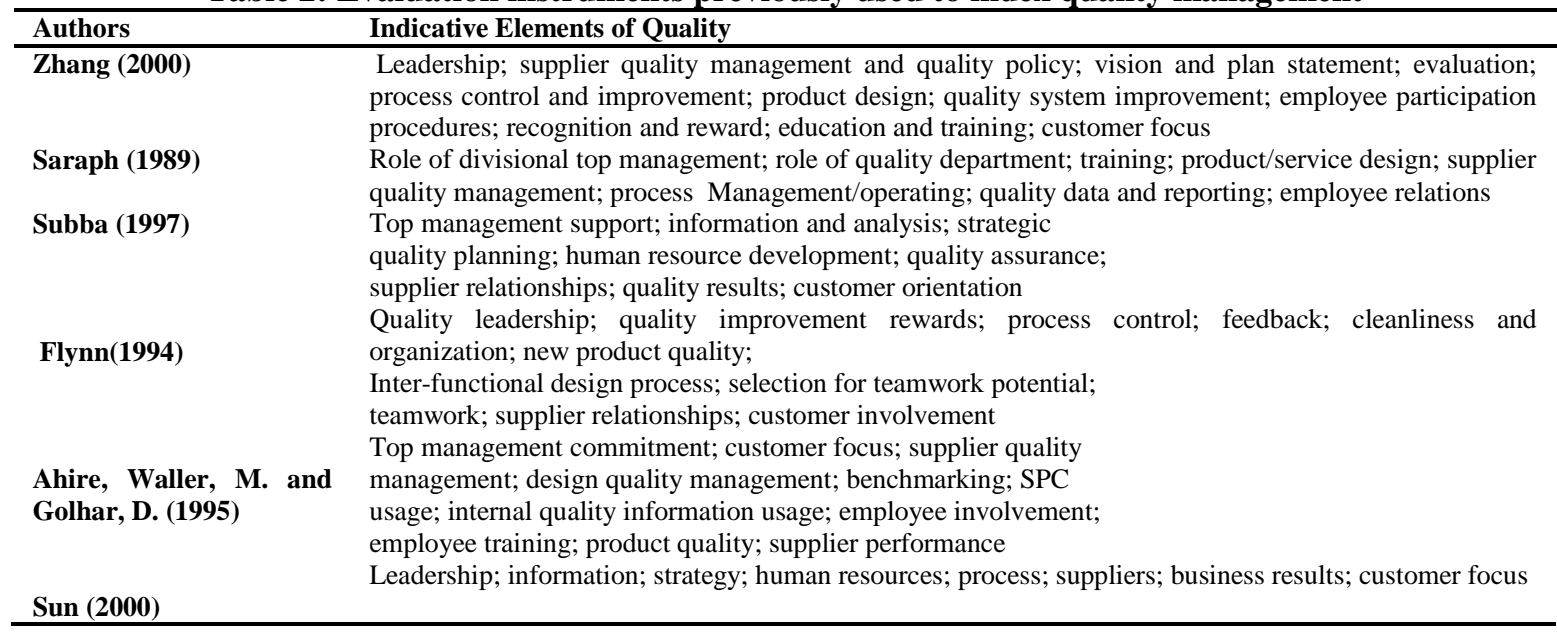

\section{Critical Review}

Schroeder (2001) identified the nine common TQM practices as cross-functional product design, process management, supplier quality management, customer involvement, information and feedback, committed leadership, strategic planning, cross-functional training, and employee involvement. Schroeder (2001) failed to explain how each of these TQM practices affects organization performance. According to Resource Based Theory resources are inputs into a firm's production process; can be classified into three categories as; physical capital, human capital and organizational capital (Crook, 2008). However this theory fails to explain the nature of resources required by organizations in order to facilitate effective implementation of quality management systems and realize increased organization performance.

As discussed in both theoretical and empirical literature, past studies are yet to determine the effect of quality management practices on the performance of food processing firms and instead explored other aspects of quality management practices such as TQM, ISO standards. While quality management systems have gained widespread attention, their effectiveness is questionable. Some studies claim that the implementation of these standards is beneficial for the firms (Koc, 2007; Wu and Liu, 2010; Marin and Ruiz-Olalla, 2011) while other studies doubt it (Taylor and Taylor, 2004; Dimara et al., 2004; Azanza and Zamora-Luna, 2005; Morris, 2006). Much research has been directed towards establishing the effects of ISO 9001 or ISO 22000 certification (Aggelogiannopoulos et al, 2007; Arvanitoyannis and Varzakas, 2008; Bayati and Taghavi, 2007; Benner and Veloso, 2008).

The HACCP system per se does not make safe food, but its correct and effective application can make the difference. In order for this to be achieved, the barriers of implementing HACCP should be assessed and their impact evaluated (Eves and Dervisi, 2005). Taylor and Kane (2005) noted that there is a need to identify the specific hurdles that companies face at each step of the HACCP process and to develop successful intervention strategies. Until these barriers be resolved, HACCP system will not be effectively implemented throughout the whole food chain and it will not be able to reach its full potential as prerequisite for the international trade of foodstuffs (Panisello and Quantick, 2001; Eves and Dervisi, 2005). Future food quality management researches and analyses should therefore be focused on assessing, quantifying and modelling those technological and managerial factors that contribute to food quality, on the dynamic behavior of these factors, and on how this behavior can be conditioned (Luning and Marcelis, 2007). 
Luning et al. (2008) also stated that quantitative studies should be carried out in different food sectors in order to get more in-depth and specific insight in the major factors influencing the effectiveness of food safety management systems. As far as company competitive performance is concerned, the competitive capabilities such as quality, cost delivery, flexibility and time have been used in many empirical research studies (Leong et al., 1990; Madu et al., 1995; Ward et al., 1995; Vickery et al., 1997; Jayaram et al., 1999; Kathuria, 2000) in order to explore a company's competitive performance. Zhang (2001) refers that the competitive capability of a company is created as a result of its quality practices. Hoyle (1995) states that when a quality system is being established it is necessary to measure whether the system is being effective because an effective quality system enhances the competitive abilities of a company and provides strategic advantages in the market place (Anderson et al. 1995). However, according to van der Spiegel et al. (2007), a company having established a quality system should test its effectiveness by evaluating the degree to which its pre-established objectives have been met. A study by Voss (2007) developed model of service management to establish a benchmark against which the quality management practices affects performance of 310 UK and US organizations. The study was undertaken in US and UK and hence the obtained findings cannot be used to reflect quality management problems in Kenya.

The study also failed to explore the specific quality management practices that influence organizations performance. A study by Anderson (2009) noted that, many food processing firms are currently struggling to embrace effective quality management systems in order to meet customers' demands in the global market. This study however failed to explain the major challenges affecting implementation of quality management systems in food processing firms and how quality management systems could enhance realization of increased organization performance

\section{Conclusion}

Literature on quality managements systems depicts improvements in business performance. A conceptual model to explain the relationship between the independent variable and quality management systems and performance has been presented.

Findings illustrate that benefits of quality management systems includes, improved communication within the organization, increased process efficiency and improved human resource management. However, quality managements systems have been criticized as being costly and time-consuming.

\section{References}

[1]. Agus, A. (2000). TQM practices in manufacturing companies in Malaysia. An Exploratory Total Quality Management, 11(8), pp 104-51.

[2]. Aggelogiannopoulos, D., Drossinos, H. and Athanasopoulos, P. (2007). Implementation of a quality management system according to the ISO 9000 family in a Greek small-sized winery, a case study. Food Control, 18 (9), pp. 1077-85.

[3]. Ahire, S., Waller, M. and Golhar, D. Y. (1995). Quality management in TQM firms: An empirical study. International Journal of Quality and Reliability Management, 13, pp 8-27.

[4]. Alison, D. (2008). Best predictors of quality performance in Australian service organizations. Managing Service Quality, 8 (5), pp.359- 366 .

[5]. Anderson, S.W., Daly, J.D. and Johnson, M.F. (1999). Why firms seek ISO 9000 certification: Regulatory compliance or competitive advantage? Production Operations Management, Vol. 8, pp. 28-43.

[6]. Antony, J., leung, K., Knowles, G. and Gosh, S. (2002). Critical success Factors of TQM implementation in Hong Kong industries. International Journal of Quality \& Reliability Management, Vol. 19 No. 5, pp. 551-566.

[7]. Armstrong, M. (2010). Strategic Human Resource Management: A Guide to Action. London: United Kingdom. Kogan Page Ltd.

[8]. Arvanitoyannis I.S., Varzakas T.H. (2008). Application of ISO 22000 and Failure Mode and Effect Analysis (FMEA) for industrial processing of salmon: A case study. Critical Review Food Science \&Nutrition, 48, pp 411-429.

[9]. Azanza, M. P. V., \& Zamora-Luna, M. B. V. (2005). Barriers of HACCP team members to guideline adherence. Food Control, $16(1), 15 \mathrm{e} 22$.

[10]. Bayati, A. and Taghavi, A. (2007). The impacts of acquiring ISO 9000 certification on the performance of SMEs in Tehran. The TQM Magazine, Vol. 19 No. 2, pp. 140-9.

[11]. Bell, M. and Omachonu, V. (2011). Quality system implementation process for business success. International Journal of Quality \& Reliability Management, Vol. 28 No. 7, pp. 723-34.

[12]. Bell J. (2010). Doing your Research Project. Buckingham: Open University Press.

[13]. Benner, M.J. and Veloso, F.M. (2008). ISO 9000 practices and financial performance: a technology coherence perspective. Journal of Operations Management, Vol. 26 No. 6, pp. 611-29.

[14]. Bidco Oil Kenya Limited, http://www.bidco-oil.com. Accessed 30 July 2013

[15]. Burlingame, B. and Pineiro, M. (2007). The essential balance: risks and benefits in food safetyand quality. Journal of Food Composition and Analysis, Vol. 20 Nos 3-4, pp. 139-46.

[16]. Brah, S.A., Tee, S.S.L. and Rao, B.M. (2002). Relationship between TQM and performance of Singapore companies. International Journal of Quality and Reliability Management 9(4): 356-379.

[17]. Calisir, F. (2007). Factors affecting service companies's satisfaction with ISO 9000. ManagingService Quality, Vol. 17 No. 5, pp. 579-93.

[18]. Chapman, R. and Al-Khawaldeh, K. (2002). Quality management worldwide: TQM and labour productivity in Jordanian industrial companies. The TQM Magazine, 14 (4), pp 248-62.

[19]. Chen, C. (2008). Quality management practices and quality results: a comparison of manufacturing and service sectors in Taiwan. Managing Service Quality, Vol. 8 No.1, pp.46-54. 
[20]. Cheng, S.P., and Tummala, V.M.R (1998). An employee involvement strategy for ISO 9000 registration and maintenance: A case Study for Hong Kong and China companies. International Journal of Quality \& Reliability Management, Vol. 15 No. 8/9, pg. 860.

[21]. Chow-Chua, C., Goh, M. and Wan, T. (2003). Does ISO 9000 certification improve business performance?. International Journal of Quality \& Reliability Management, Vol. 20 No. 8.

[22]. Codex Alimentarius Commission (2003). Recommended International Code of Practice General

[23]. Principles of Food Hygiene, Joint FAO/WHO Food Standards Programme, available at: www.codexalimentarius.net/web/standard_list (accessed January 2013 ).

[24]. Codex Alimentarius Commission (CAC) (2001). "Proposed draft revised guidelines for the

[25]. application of the HACCP system in small and/or less developed businesses (SLDBs)., Joint FAO/WHO Food Standards Programme Codex Committee on Food Hygiene, Report of the 34th Session, Agenna Item 10, CX/FH 01/10, CAC, Rome.

[26]. Cooper, D.R. and Schindler, P.S. 2001. Business Research Methods. 7th Edition. McGraw-Hill. Irwin. United State of America

[27]. Conca, F.J., Llopis, J. and Tari, J.J. (2004). Development of a measure to assess quality management in certified firms. European Journal of Operational Research, 156: 683 - 697.

[28]. Crosby, P.B. (2009). Quality Is Free: The Art of Making Quality Certain. New York: New American Library.

[29]. Dale, B. G., Boarden, R. J. and Lascelles, D. M. (1994).Total quality management: An overview in Dale, B.G.(Ed) Managing Quality. (2nd edn.). London: Prentice-Hall pp. 1-40.

[30]. Damikouka I., Tzia K.C.(2007). Application of HACCP principles in drinking water treatment. Desalination, 210, 138-145

[31]. Dean, J.W. and Bowen, D.E. (1994). Management theory and total quality management: Improving research and practice through theory development. Academy of Management

[32]. Review, Vol. 19 No. 3, pp. 392-418.

[33]. Dempsey,B. (2003). Research Methods. New Jersey: Pearson Prentice Hall Publishers.

[34]. Donaldson S.I., Grant-Vallone E. J. (2002). Understanding self-report bias in Organizational behavior research. Journal of business and psychology, vol. 17, No. 2

[35]. Dimara, E., Skuras, D., Tsekouras, K. \& Goutsos, S. (2004). Strategic orientation andfinancial performance of firms implementing ISO9000. International Journal of Quality \& Reliability Management, Vol.21, No.1, pp.72-89.

[36]. Domenech, E., Escriche, I. and Martorell, S. (2008). Assessing the effectiveness of critical control points to guarantee food safety. Food Control, Vol. 19 No. 6, pp. 557-65.

[37]. Ehiri, E., Morris, P. and McEwen, J. (1995). Implementation of HACCP in food businesses:the way ahead. Food Control, Vol. 6 No. 6, pp. 341-5.

[38]. Eves, A. and Dervisi, P. (2005). Experiences of the implementation and operation of hazardanalysis critical control points in the food service sector. Hospitality Management, Vol. 24, pp. 3-19.

[39]. ELOT (2005). ISO 22000:2005: Food safety management systems - requirements for any organization in the food chain. Hellenic Body Organisation for Standardisation (ELOT),Athens.

[40]. Evans, J. R., \& Lindsay, W. M. (2004). The Management and Control of Quality. St. Paul: West Publishing Company.

[41]. FAO/WHO (2002). Pan European conference on food safety and quality, Budapest, Hungary, available at: www.fao.org/docrep/fao/meeting/004/y3696e00.pdf (accessed 7 June 2013).

[42]. Feng, M., Terziovski, M. and Samson, D. (2008). Relationship of ISO 9001:2000 quality system certification with operational and business performance. Journal of Manufacturing Technology Management, Vol. 19 No. 1, pp. 22-37.

[43]. Flynn, B.B., Schroeder, R.G. \& Sakakibara, S. (1995). The impact of quality management practices on performance and competitive advantage. Decision Sciences, Vol. 26, No. 5, pp. 659-691.

[44]. Fotopoulos, C. and Psomas, E. (2010). The structural relationships between TQM factors and Organizational performance. The TQM Journal, Vol. 22 No. 5, pp. 539-52.

[45]. Fotopoulos, C., Kafetzopoulos, D. and Psomas, E. (2009). Assessing the critical factors and their impact on the effective implementation of a food safety management system. International Journal of Quality \& Reliability Management, Vol. 26 No. 9, pp. 894-910.

[46]. Fotopoulos, C., Psomas, E. and Vouzas, F. (2010). ISO 9001:2000 implementation in the Greek food sector. The TQM Journal, Vol. 22 No. 2, pp. 129-42.

[47]. Hayati T. H. A., Ali, K. A. M. and Idris, F. (2012). Quality management framework for the SME's food processing industry in Malaysia.International Food Research Journal 20(1): 147-164

[48]. Ho, S.K.M. \& Fung, C.K.H.(1994). Developing a TQM excellence model. The TQM Magazine, Vol.6. no.6., pp. 24-30.

[49]. Idris, M.A. and Zairi, M. (2006). Sustaining TQM: a synthesis of literature and proposed research framework. Total Quality Management, Vol. 17 No. 9, pp. 1245-60.

[50]. Kathuria, R. (2000). Competitive priorities and managerial performance: A taxonomy of small manufacturers. Journal of Operations Management, Vol. 18 No. 6, pp. 627-41.

[51]. Koc, T. (2007). The impact of ISO 9000 quality management systems on manufacturing. Journal of Materials Processing Technology, Vol. 186 Nos 1-3, pp. 207-13.

[52]. Kothari, C. R. (2004). Research Methodology; Methods and Techniques. New Delhi: New Age International (P) Ltd. Publishers.

[53]. Lakhal, L., Pasin, F. and Limam, M. (2006). Quality management practices and their impact on performance. International Journal of Quality and Reliability Management, 23(6): 625-646.

[54]. Loc, V.T.T. (2006). Seafood supply chain quality management: the shrimp supply chain quality improvement perspective of seafood companies in the Mekong Delta, Vietnam,

[55]. Luning, P. and Marcelis, W. (2007). A conceptual model of food quality management functions based on a techno-managerial approach. Trends in Food Science \& Technology, Vol. 18 No. 3, pp. 159-66.

[56]. Madu, C.N., Kuei, C.H. and Lin, C. (1995). A comparative analysis of quality practice in manufacturing firms in the US and Taiwan. Decision Sciences, Vol. 26, pp. 621-35.

[57]. Mady, M.T. (2009). Quality management practices: an empirical investigation of associated constructs in two Kuwaiti industries. International Journal of Quality \& Reliability Management, Vol. 26 No. 3, pp. 214-33.

[58]. Magd, H. (2008). ISO 9001:2000 in the Egyptian manufacturing sector: Perceptions and perspectives. International Journal of Quality \& Reliability Management Vol. 25 No. 2, pp. 173-200.

[59]. Marin, L.M. and Ruiz-Olalla, M.C. (2011). ISO 9000:2000 certification and business results. International Journal of Quality \& Reliability Management, Vol. 28 No. 6, pp. 649-61.

[60]. McMahon, R.G.P. (2001). Deriving an empirical development taxonomy for manufacturing SMEs using data from Australia's business longitudinal survey. Small Business Economics 17(3), 197-212.

[61]. McAdam, R. and Henderson, J. (2004). Influencing the future of TQM: internal and external driving factors. International Journal of 
Quality and Reliability Management 21(1): 51-71.

[62]. Morris, P.W. (2006). ISO 9000 and financial performance in the electronics industry. Journal of American Academy of Business, Vol. 8 No 2, pp. 227-235.

[63]. Morris, S. (2001). Data analysis methods. New Jersey: Pearson Prentice Hall Publishers.

[64]. Mortimore, S. (2001). How to make HACCP really work in practice. Food Control, Vol. 12 No. 4, pp. 209-15.

[65]. Mugenda A. (2008). Research Methods (3rd Ed). Nairobi: Jomo Kenyatta Publishers.

[66]. Musa, N. (2008). Innovation and competitiveness through Halal certification. Thirteen International Conference on ISO9000 and TQM, Kuala Lumpur. Malaysia. paper 03-08.

[67]. Panisello, P. and Quantick, P. (2001). Technical barriers to Hazard Analysis Critical Control

[68]. Point (HACCP). Food Control, Vol. 12 No. 3, pp. 165-73.

[69]. Powpaka, S. (2009). The role of outcome quality as a determinant of overall service quality in different categories of services industries: An empirical investigation. Journal of Services Marketing, Vol. 10 No.2, pp.5-25.

[70]. Rategan, C. (2008). Total Quality Management. Journal of Property Management, Vol. 57, pp. 32-34.

[71]. Roth, A.V. (2009). Competitiveness of UK service: An Anglo-US benchmark comparison of service practice and performance. Severn Trent plc, UK Government's Department of Trade and Industry.

[72]. Serekan, U.(2003). Research Methods for Business: A Skill Building Approach. (4 ${ }^{\text {th }}$ ed.). New York: John Willy \& Sons Inc.

[73]. Sharma, M. and Kodali, R. (2008). TQM implementation elements for manufacturing excellence, The TQM Magazine, Vol. 20 No. 6, pp. 599-621.

[74]. Singh, P. (2008). Empirical assessment of ISO 9000 related management practices and performance relationships. International Journal of Production Economics, Vol. 113, No. 1, pp. 40-59.

[75]. Singh, P., Feng, M. and Smith, A. (2006). ISO 9000 series of standards: comparison of manufacturing and service organizations. International Journal of Quality \& Reliability Management, Vol. 23 No. 2, pp. 122-42.

[76]. Sikora T., Nowicki P., (2007). Food safety assurance according to Codex Alimentarius and ISO 22000 Standard. Journal of Food \& Nutrition Science, 57 (4C), 489-493

[77]. Sikora, T. and Strada, A. (2006). Safety and Quality Assurance and Management Systems in Food Industry: An Overview. Cracow University of Economics, Warsaw.

[78]. Sperber, W. H. (2005). HACCP and transparency. Food Control, Vol. 16(6), p. 505-509.

[79]. Stevenson, E. and Bernard, T. (1999). HACCP: A Systematic Approach to Food Safety. FoodProcessors Institute, Washington, DC

[80]. Talbot, V. (2007). ISO 22000 Standard: A food safety management system. SPC Fisheries Newsletter, January/March, pp. 40-43.

[81]. Tari, J. and Sabater, V. (2004). Quality tools and techniques: are they necessary for qualitymanagement?. International Journal of Production Economics, Vol. 92, pp. 267-80.

[82]. Taylor, E.A. and Taylor, J.Z. (2004a). Perceptions of the bureaucratic nightmare of HACCP. British Food Journal, Vol. 106 No. 1, pp. 65-72.

[83]. Taylor, E.A. and Taylor, J.Z. (2004b). Using qualitative psychology to investigate HACCP implementation barriers. International Journal of Environmental Health Research, Vol. 14No. 1, pp. 53-63.

[84]. Terziovski, M., Samson, D. \& Dow, D. (1997). The business value of quality management systems certification: Evidence from Australia and New Zealand. Journal of Operations Management, Vol.15, pp.1-18.

[85]. Terziovski M, Power D. and Sohal A. (2003). The longitudinal effects of the ISO 9000 certification process on business performance. European Journal of Operational Research Vol.146, pp. 580-595.

[86]. Terziovski, M. and Power, D. (2007). Increasing ISO 9000 certification benefits: A continuous improvement approach. International Journal of Quality \& Reliability Management. Vol. 24 No. 2, pp. 141-163.

[87]. Trienekens, J. and Zuurbier, P. (2008). Quality and safety standards in the food industry, developments and challenges. International Journal of Production Economics, Vol. 113 No. 1, pp. 107-22.

[88]. Tvorik, S.J \& McGiven, M.H. (2007). Determinants of organizational performance. Management Decision, Vol 35 (6), pp. 417-435.

[89]. UNIHSNOR, Union of Associations of Hotels and Restaurants of Northern Portugal. Prevention Handbook ISHST (Portuguese Organization for Occupational Health and Safety - ACT), 2005, Lisbon

[90]. Van Iwaarden, J., Van der Wiele, T., Williams,R., and Dale, B. (2006). A management control perspective of quality management: An example in the automotive sector. International Journal of Quality \& Reliability Management. Vol. 23 No.1, pg. 102.

[91]. Van der Spiegel, M., Luningy, P., Ziggers, G. and Jongen, W. (2004). Evaluation of performance measurement instruments on their use for food quality systems. Critical Reviews in Food Science and Nutrition, Vol. 44 Nos 7-8, pp. 501-12.

[92]. Voss, C.A. (2007). Competitiveness of UK service: an Anglo-US benchmark comparison of service practice and performance. UK Government's Department of Trade and Industry.

[93]. Voss, C., Tsikriktsis, N., \& Frohlich, M. (2002). Case research in operations management. International Journal of Operations \& Production Management, Vol. 22 No. 2, pp. 195-219.

[94]. Wallace, C.A., Powell, S.C. and Holyoak, L. (2005). Post-training assessment of HACCP knowledge: its use as a predictor of effective HACCP development, implementation and maintenance in food manufacturing. British Food Journal, Vol. 107 No. 10, pp. 743-59.

[95]. Ward, G. (2001). HACCP: heaven or hell for the food industry?. Quality World, March, pp. 12-15

[96]. Wu, S.I and Liu, S.Y. (2010). The performance measurement perspectives and causal relationship for ISO-certified companies: A case of opto-electronic industry. International Journal of Quality \& Reliability Management, Vol. 27 No. 1, pp. 27-47.

[97]. Yang, C. (2006). Establishment of a quality-management system for service industries. Total Quality Management Vol. 17 No.9, pp. 1129-1154

[98]. Yong, J. and Wilkinson, A. (2002). The long and winding road: The evolution of quality management. Total Quality Management, 13(1), pp 101-121.

[99]. Yusof, S. M. and Aspinwall, E. (1999). Critical success factors for total quality management implementation in small and medium enterprises. Total Quality Management, 10, S803-S809.

[100]. Zhang Z. (2000). Developing a model of quality management methods and evaluating their effects on business performance. Total Quality Management, Vol. 11, Iss.1, pp.129-137.

[101]. Zinbarg,M. (2005). Research Methods. New Jersey: Pearson Publishers 